\title{
Eksistensi Kebakuan Bahasa Indonesia dalam Karya Tulis Mahasiswa
}

\author{
Ayunda Riska Puspita ${ }^{1}$, Hafidz Rosyidiana ${ }^{2}$ \\ Institut Agama Islam Negeri Ponorogo ${ }^{1}$, Institut Islam Mamba'ul Ulum Surakarta \\ puspita@iainponorogo.ac.id ${ }^{1}, \underline{\text { h.rosyid2904@gmail.com }}{ }^{2}$
}

DOI: http://dx.doi.org/10.32528/bb.v5i2.3521

First received: 27-08-2020

Final proof received: 22-09-2020

\begin{abstract}
ABSTRAK
Fenomena kesalahan berbahasa sudah semakin menjamur. Bahkan di kalangan akademis pun sudah sering ditemukan bentuk kesalahan ejaan, morfologi, kata baku, dan kalimat efektif. Penelitian ini bertujuan untuk mendeskripsikan kesalahan penggunaan bahasa yang terdapat dalam karya tulis mahasiswa PGMI IAIN Ponorogo. Pendekatan dalam penelitian ini menggunakan pendekatan kualitatif dan jenis penelitiannya adalah penelitian studi kasus dengan metode deskripsi-interpretasi. Bentuk kesalahan ejaan yang ditemukan dalam karya tulis mahasiswa PGMI IAIN meliputi kesalahan penggunaan tanda koma (,), tanda baca ganda, huruf kapital, huruf miring, tanda titik koma (;), dan tanda hubung (-). Bentuk kesalahan morfologi meliputi kesalaan afiksasi, reduplikasi, dan komposisi. Bentuk kesalahan kata baku meliputi kesalahan penulisan kata yang tidak sesuai dengan bentuk baku di (Kamus Besar Bahasa Indonesia) KBBI. Bentuk kesalahan kalimat efektif merupakan kesalahan pada kalimat yang tidak lugas, ambigu, tidak jelas, berbelit-belit, dan tidak sejajar. Terdapat pula kesalahan yang dilakukan oleh mahasiswa namun di tempat lain benar menuliskannya. Hal ini menunjukkan ketidakkonsistenan mahasiswa dalam berbahasa. Sikap seperti ini merupakan sikap bahasa yang negatif. Sebagian kasus menunjukkan bahwa sebenarnya mahasiswa mengetahui kesalahannya tapi enggan atau tidak peduli dengan hal yang sepele. Jika dibiarkan maka lambat laun bahasa Indonesia yang sesuai dengan aturan akan memudar digantikan oleh bahasa yang tanpa aturan baku.
\end{abstract}

Kata Kunci: kesalahan berbahasa; bahasa baku; masa depan bahasa Indonesia

\begin{abstract}
Language error phenomenon is getting worse. Eventhough in academic world, it is often found that there are mistakes in spelling, morphology, standard words, and effective sentences. This study aims to describe the language errors in the papers of PGMI IAIN Ponoro go students.This research use qualitative approach and the type is a case study with a description-interpretation method. The spelling errors found in students' papers include the misuse of commas (,), double punctuation marks, capital letters, italics, semicolons (;), and hyphens (-). The morphological
\end{abstract}


errors include affixation, reduplication, and composition negligence. The standard word errors include writing errors that are words that do not correspond to the standard form on the KBBI. The effective sentence errors are mistakes in sentences that are not straightforward, ambiguous, unclear, convoluted, and misaligned.There are also mistakes made by students but in other places it is right to write it down. This shows their inconsistency in language. This attitude is a negative language attitude. Some cases show that students actually know their mistakes but are reluctant or don't care about trivial matters If left unchecked, gradually Indonesian language that conforms to the rules will fade, replaced by language without standard rules.

\section{Keywords: language errors; standard language; the future of Indonesian}

\section{PENDAHULUAN}

Asal mula bahasa Indonesia adalah berasal dari bahasa Melayu. Sejarah perjalanan bahasa Indonesia dari tanah Melayu sampai ke pelosok Nusantara sangatlah panjang, melalui perdebatan dan pemikiran-pemikiran pencetus "Bahasa Indonesia" yang mulai diikrarkan pada peristiwa Sumpah Pemuda. Untuk mencetuskan bahasa persatuan inilah nilai-nilai perjuangan pemuda-pemuda pada tahun 1920-an patut mendapatkan apresiasi yang baik dari penerus bangsa.

Pada mulanya bahasa Indonesia adalah bahasa Melayu yang digunakan sebagai lingua franca di Nusantara. Bahasa Melayu dari tanah Sumatera ini tersebar ke seluruh pelosok Nusantara melalui perdagangan. Endarmoko (2017: 18-19) menyebutkan bahwa M. Yamin adalah pencetus pentingnya bahasa persatuan (disampaikan pada lustrum pertama Jong Sumatranen Bond tahun 1923). Pemikiran M. Yamin ini disampaikan kembali pada Kongres Pemuda I (tahun 1926) dan memilih bahasa Melayu sebagai bahasa persatuan. Akhirnya pada Kongres Pemuda II (tahun 1928) ditetapkan bahasa Melayu sebagai bahasa persatuan. Sempat terlontar pula untuk memilih bahasa Jawa sebagai bahasa persatuan, dengan pertimbangan penutur bahasa Jawa lebih banyak dibandingkan penutur bahasa Melayu. Menariknya, justru banyak pemuda dari Jawa yang menolak usulan tersebut. Atas saran Poerbatjaraka yang menyetujui usulan M. Yamin, maka dipilihlah bahasa Melayu sebagai bahasa kebangsaan. Bahasa persatuan tersebut diubah namanya menjadi bahasa Indonesia dalam Sumpah Pemuda.

Cita-cita komunitas majemuk pada tahun 1920-an itu-yang punya niat saling mempertalikan diri dengan satu bahasa yang sama, dan kemudian menyebut diri "bangsa Indonesia"- kini dihadapkan pada soal-soal yang pelik Edarmoko (2017: 9). Persoalan ini datang dari banyak pihak. Salah satu persoalan yang akan dikaji dalam artikel ini adalah permasalahan kebahasaan di dunia pendidikan, khususnya yang ada di dunia kampus yang di dalamnya terdapat agen-agen pelaksana cita-cita komuitas majemuk tahun 1920-an tersebut.

Di beberapa institusi pendidikan, penghargaan terhadap bahasa Indonesia masih kurang. Bahasa Indonesia masih didiskriminasikan. Bahasa Indonesia masih kalah pamor dengan bahasa asing, khususnya bahasa PBB, seperti bahasa Arab dan bahasa Inggris. 
Berdasarkan pengalaman mengajar mata kuliah Bahasa Indonesia di IAIN Ponorogo dari beberapa jurusan yang berbeda, masih ditemukan berbagai macam kesalahan. Penulisan karya ilmiah mengguakan bahasa Indonesia yang baik dan benar merupakan tujuan utama dalam pembelajaran Bahasa Indonesia. Materi yang didiskusikan meliputi penggunaan ejaan bahasa Indonesia yang tepat sesuai dengan PUEBI, pemilihan diksi yang tepat dalam penulisan, penggunaan kalimat efektif, dan penulisan paragraf yang baik. Hasil koreksi teman sebaya menunjukkan masih banyak dijumpai kesalah dalam materi-materi tersebut. Bahkan, setelah dikoreksi ulang, koresksi yang dilakukan oleh teman sebaya tersebut masih banyak yang kurang tepat atau dengan kata lain mereka yang mengoreksi juga belum paham sekali penulisan bahasa Indonesia yang baik sesuai dengan konteks dan benar sesuai dengan aturan yang berlaku.

Data penelitian ini diambil di Fakultas Tarbiyah dan Ilmu Keguruan dengan alasan bahwa Fakultas Tarbiyah dan Ilmu Keguruan fokus di bidang pendidikan dan pencetak guru profesianal. Nanti gurulah yang akan menjadi penggerak kemajuan bahasa Indonesia karena guru adalah pencetak generasi bangsa yang dalam pembelajarannya wajib menggunakan bahasa Indonesia. Masa depan Indonesia, khususnya masa depan bahasa Indonesia bergantung pada guru. Hal itu disebabkan oleh peran guru dalam mempertahankan bahasa Indonesia salah satunya dengan menyampaikan materi pembelajaran menggunakan bahasa Indonesia.

Lebih spesifik lagi, penelitian ini mebidik jurusan Pendidikan Guru Madrastah Ibtidaiyah (PGMI). Guru di tingkat dasar seperi SD/MI merupakan faktor penentu keberhasilan anak di masa depan, khususnya dalam menerapkan sikap-sikap positif karena usia SD/MI adalah usia yang tepat untuk membentuk karakter yang baik. Pada era globalisasi seperti saat ini, perkembangan ilmu pengetahuan dan teknologi semakin pesat. Segalanya dituntut untuyk cepat. Guru mengemban peran yang penting dan sangat strategis dalam mengupayakan pembentukan perilaku siswa yang berkarakter sesuai nilai-nilai budaya bangsa Negara Indonesia (Santoso, 2017:168).

Permasalahan-permasalahan di atas menunjukkan adanya kondisi bahasa Indonesia yang semakin memprihatikan di kalangan mahaasiswa IAIN Ponorogo. Oleh karena itu, dalam penelitian ini akan mendeskripsikan kesalahan yang terjadi pada penulisan karya ilmiah mahasiswa. Dengan adanya deskripsi kesalahan berbahasa mahasiswa tersebut selanjutnya dapat diketahui kondisi sebenarnya yang terjadi, sehingga dapat ditentukan masa depan bahasa Indonesia yang terdapat dalam karya tulis mahasiswa dan dapat pula dirancang penyelesaian masalah ini.

Beberapa penelitian terdahulu tentang analisis kesalahan berbasa di antaranya adalah Analisis Kesalahan Berbahasa Indonesia secara Sintaksis dalam Proses Diskusi Siswa Kelas IV SDN Miri. Penelitian tersebut ditulis oleh Gio Mohamad Johan dan Yusrawati JR Simatupang (2017: 241). Selanjutnya penelitian serupa juga dilakukan oleh Reni Supriani dan Ida Rahma Siregar (2016: 67-76) dengan judul "Penelitian Analisis Kesalahan Berbahasa". Satu lagi ada penelitian dari Ayudia, Edi Suryanto, dan Budhi Waluyo (2016: 34-49) yang berjudul Analisis Kesalahan Penggunaan Baahsa Indonesia dalam Laporan Hasil Observasi pada Siswa SMP”. Penelitian-penelitian terdahulu tersebut menampilkan analisis kesalahan berbahasa tanpa mempertimbangkan 
refleksinya terhadap masa depan bahasa Indonsia. Dalam penelitian ini peneliti akan menyampaikan refleksi masa depan bahasa Indonesia dalam karya tulis mahasiswa dilihat dari kesalahan berbahasa yang dilakukan oleh mahasiswa.

\section{METODE PENELITIAN}

Penelitian ini merupakan penelitian yang menggunakan pendekatan kualitatif. Jenis penelitian ini adalah studi kasus (case study). Yin (dalam Rahardjo: 2017: 4) menyabutkan bahwa dalam penelitian studi kasus selain pertanyaan apa (what), studi kasus juga mempertanyakan pertanyaan bagaimana (how) dan mengapa (why).

Data dalam penelitian ini merupakan karya tulis mahasiswa PGMI IAIN Ponorogo kelas GMI.F. Data yang dianalisis adalah bahasa tulis dalam karya tulis mahasiswa GMI.F. Bahasa tulis tersebut meliputi penulisan ejaan, kata, dan kalimat. Dipilih GMI.F karena kelas ini kelas dengan kemampuan mahasiswa yang heterogen sehingga kesalahan berbahasa Indonesia yang ditemukan akan bervariasi. GMI.F juga telah mendapatkan seluruh materi kebahasaan (ejaan, kata, dan kalimat) tersebut sebelum membuat karya tulis. Jadi mereka bukanlah kertas kosong tanpa pengetahuan kebahasaan yang baku.

Seperti yang disebutkan sebelumnya bahwa studi kasus menjawab tiga pertanyaan, yakni what, how, dan why, maka penelitian ini akan menjawab ketiga pertanyaan tersebut. Pertanyaan apa (what) dalam penelitian ini untuk mendeskripsikan kesalahan berbahasa pada karya tulis mahasiswa. Pertanyaan bagaimana (how) untuk menjelaskan proses terjadinya kesalahan berbahasa. Selanjutnya, pertanyaan mengapa (why) untuk menjelaskan alasan terjadinya kesalahan berbahasa yang dilakukan oleh mahasiswa. Selain itu, penelitian ini juga menggunakan teknik deskriptif-interpretatif. Penelitian deskriptif adalah penelitian yang menggunakan metode deskriptif yaitu metode yang dilakukan semata-mata hanya berdasarkan fakta yang ada atau fenomena pada penututrnya (Sudaryanto, 1992:62). Untuk menjelaskan eksistensi bahasa Indonesia dalam karya tulis mahasiswa digunakan metode interpretasi kasus yang terjadi dalam kesalahan berbahasa dan mengaitkan dengan teori-teori terkait sikap bahasa.

Langkah-langkah penelitian ini meliputi (1) mengumpulkan data dengan teknik catat, (2) klasifikasi data, (3) analisis data dengan teknik deskriptif-interpretatif, dan (4) menyimpulkan hasil analisis. Dalam penelitian ini, sampel data dipilih dengan teknik random sampling. Selanjutnya adalah tahap pengklasifikasian data. Dalam tahap ini, data yang berupa bahasa tulis diklasifikasikan berdasarkan bentuk kesalahannya. Data yang telah diklasifikasikan kemudian dianalisis dengan mendeskripsikan kesalahannya dan menunjukkan bentuk yang tepat sesuai dengan aaturan yang berlaku yaitu PUEBI, KBBI, dan syarat kalimat efektif. Selanjutnya hasil analisis kesalahan berbahasa tersebut diinterpretasikan untuk menunjukkan masa depan bahasa Indonesia berdasarkan kesalahan-kesalahan berbahasa yang ditemukan dalam karya tulis mahasiswa.

\section{PEMBAHASAN}

Dalam artikel ini pembahasan secara garis besar terbagi menjadi dua bagian. Pertama adalah bagian analisis kesalahan berbahasa dalam karya tulis mahasiswa. Bagian kedua adalah menjelaskan refleksi masa depan bahasa Indonesia berdasarkan hasil analisis 
kesalahan berbahasa tersebut. Penjelasan kedua bagian tersebut secara lebih rinci dijelaskan di bawah ini.

\section{A. Kesalahan Berbahasa Indonesia pada Tataran Ejaan}

Ejaan adalah kaidah penulisan huruf (kata atau kalimat) serta penggunaan tanda baca (Badan Bahasa Kemendikbud RI, 2018). Berdasarkan pengertian ejaan tersebut, maka bahasa tulislah yang menjadi konsentrasi ejaan. Aturan mengenai ejaan bahasa Indonesia tersebut terdapat dalam PUEBI (Pedoman Umum Ejaan Bahasa Indonesia).

PUEBI merupakan produk pembaruan PUEYD (Pedoman Umum Ejaan Yang Disempurnakan) edidsi ketiga (Tim Pengembang Pedoman Bahasa Indonesia, 2016: ix). PUEBI diterbitkan pada tahun 2016 berdasarkan Peraturan Menteri Pendidikan dan Kebudayaan Republik Indonesia Tahun 2015. Di dalam PUEBI dipaparkan aturan-aturan penggunaan ejaan bahasa Indonesia. Jadi, PUEBI inilah yang menjadi acuan dalam menganalisis kesalahn penggunaan ejaan bahasa Indonesia dalam penelitian ini.

Penggunaan ejaan merupakan permasalahan yang sederhana tetapi sangat riskan jika terjadi kesalahan ejaan dalam penggunan bahasa tulis. Ragam bahasa lisan menggunakan sarana bunyi bahasa dan intonasi, sedangkan ejaan berhubungan dengan ragam bahasa tulis melalui sarana huruf dan tanda baca (Pusat Bahasa Departemen Pendidikan Nasional, 2001: 1-2). Dengan demikian, ejaan dalam bahasa tulis dapat mewakili bunyi dan intonasi, sehingga jika terjadi kesalahan penulisan ejaan dapat menimbulkan kesalahpahaman pembaca. Jadi penggunaan ejaan yang tepat sangat diperlukan agar tidak terjadi kesalahpahaman pembaca dalam memahami teks.

Ditemukan beberapa kesalahan ejaan dalam karya tulis mahasaiswa. Kesalahan ejaan bahasa Indonesia dalam karya tulis mahasiswa tersebut dijelaskan sebagai berikut.

Kesalahan penggunaan tanda koma (,). Kesalahan ini ditemukan pada beberapa kasus seperti (1) .... mengelola, mengatur agar lebih ....dan (2) Berkenaan dengan itu dilakukan....... .... Pada kasus (1) untuk dua hal yang dirinci tidak perlu menggunakan tanda koma melainkan menggunakan konjungsi dan. Pada kasus (2) tanda koma seharusnya diletakkan setelah konjungsi antarkalimat, sehingga bentuk yang benar adalah Berkenaan dengan itu, dilakukan......

Penggunaan tanda baca ganda. Keraguan terhadap kalimat tanya dalam sebuah paragraf mengakibatkan digunakannya tanda baca ganda. Mahasiswa berasumsi bahwa kalimat selalu diakhiri tanda titik (.). Padahal tanda akhir dalam kalimat bahsa tulis itu ada tiga, yakni tanda titik (.), tanda tanya (?), dan tanda seru (!). Contoh kesalahan dalam penggunaan tanda baca ganda adalah Tapi yang menjadi PR kita semua adalah mengapa banyak pelajar dan Mahasiswa lebih mencintai budaya asing daripada budaya sendiri?., seharusnya kalimat tersebut cukup diakhiri dengan tanda tanya karena kalimat tersebut merupakan kalimat tanya.

Kesalahan penggunaan huruf kapital. Contoh kesalahan penggunaan huruf kapital ditemukan dalam beberapa bentuk. Pertama, penulisan peristiwa penting, misalnya penulisan sumpah pemuda yang seharusnya Sumpah Pemuda. Kedua, penulisan nama tempat, misalnya indonesia dan negara Indonesia seharusnya Indonesia dan Negara Indonesia. Ketiga, penulisan kata yang bukan kata sapaan menggunakan huruf kapital, 
misalnya Mahasiswa seharusnya mahasiswa. Keempat, penulisan kata yang terpengaruh oleh penulisan singkatannya, misalnya Sumber Daya Manusia seharusnya sumber daya manusia meskipun penulisan singkatannya menggunakan huruf kapital, yakni SDM. Kelima, penulisan nama orang tidak menggunakan huruf kapital, misalnya lawrence kohlberg seharusnya Lawrence Kohlberg. Keenam, penulisan singkatan bukan nama yang seharusnya ditulis meggunakan huruf kapital dan tidak diberi tanda titik, misalnya ktsp seharusnya KTSP. Ketujuh, penulisan mata pelajaran ditulis dengan huruf kecil, misalnya geografi seharusnya Geografi.

Kesalahan penggunaan huruf miring. Kata dalam bahasa asing, termasuk bahasa Inggris, Jawa, Arab, dan bahasa lain selain bahasa Indonesia harus ditulis miring. Hal ini bertujuan untuk membedakan bahasa Indonesia dan bahasa yang lain dalam satu teks. Beberapa mahasiswa tidak menggunakan huruf miring dalammenulisbahasaasing, misalnya home schooling, survive, genetic, dan susceptibility. Kata-kata tersebut seharusnya ditulis menggunakan huruf miring, yakni home schooling, survive, genetic, dan susceptibility.

Kesalahan penggunaan tanda titik koma (;). Kesalahan ini banyak sekali terjadi pada kasus pencontohan. Mahasisiwa belum memahami fungsi tanda baca titik dua ini. Contoh kesalahan yang ditemukan dalam karya tulis mahasiswa adalah ...... sudah mempraktekan home schooling, seperti; KH. Agus Salim ..... Seharusnya tanda titik dua tidak perlu diguanakan karena fungsi tanda titik dua tidak sama dengan fungsi tanda titik dua dan tidak tepat jika digunakan setelah kata seperti. Pembenaran dari kesalahan tersebut adalah ..... sudah mempraktekan home schooling, seperti KH. Agus Salim .....

Kesalahan tanda hubung. Tanda hubung sering disamakan fungsinya dengan tanda pisah. Tanda hubung berfungsi untuk menghubungkan dua morfem yang seharusnya dirangkai namun memiliki bentuk yang sama. Contoh kesalahan penggunaan tanda hubung adalah 9-10tahun. Tanda yang digunakan untuk menyatakan makna 'sampai dengan' seharusnya adalah tanda pisah (-). Dalam PUEBI disebutkan bahwa salah satu makna tanda hubung adalah 'sampai dengan'. Sehingga bentu yang tepat adalah 9-10 tahun.

Selain kesalahan-kesalahan tersebut, ditemukan beberapa kesalahan yang sebenarnya merupakan kesalahan sepele tapi dilakukan berulang kali. Kesalahan tersebut adalah setelah tanda baca titik dan/atau koma seharusnya dispasi. Kesalahan sepele yang berulang ini tidak hanya dilakukan oleh satu mahasiswa, namun beberapa mahasiswa. Kesalahan seperti ini seharusnya sudah tidak lagi menjadi masalah bagi penutur asli bahasa Indonesia.

\section{B. Kesalahan Berbahasa Indonesia pada Tataran Morfologi}

Morfologi merupakan salah satu cabang Linguistik yang mengkaji tentang pembentukan kata. Katamba (1993:19) mengungkapkan bahwa morfologi adalah kajian tentang struktur kata. Muslich (2009) menyebutkan bahwa pembentukan kata dan struktur kata dalam Bahasa Indonesia dapat dibentuk melalui tiga proses, afiksasi (pengimbuhan), reduplikasi (pengulangan), dan komposisi (pemajemukan). Ketiga jenis proses pembentukan kata tersebut dalam Bahasa Indonesia memiliki aturan kebakuan dalam 
penulisannya. Oleh karena itu, tidak dianjurkan untuk menuliskan kata berafiks sekehendak penulis tanpa memperhatikan peraturan yang sudah ada.

Berdasarkan analisis terhadap karya tulis mahasiswa PGMI yang menempuh mata kuliah Bahasa Indonesia ditemukan kesalahan berbahasa Indonesia pada tataran morfologi meliputi kesalahan pada proses afiksasi, reduplikasi, dan komposisi. Frekuensi kesalahan terbanyak adalah kesalahan penulisan afiksasi.

Pertama, kesalahan yang ditemukan adalah kesalahan penulisan afiksasi pada bahasa Indonesia. Kesalahan penggunaan prefiks (awalan) $d i$ - sangat sering ditemukan di setiap karya tulis mahasiswa. Contoh kesalahan penulisan prefiks di- adalah di tentukan, di padu, di ajarkan, di banding, dan di sebutkan. Penulisan prefiks di- seharusnya dirangkai dengan kata dasarnya, sehingga menjadi ditentukan, dipadu, diajarkan, dibanding, dan disebutkan. Kondisi tersebut berlawanan dengan penulisan di sebagai kata depan yang penulisannya dipisahkan dari kata dasarnya. Contoh kesalahan penulisan di sebagai kata depan dilingkungan, dibeberapa, diantaranya, dimana, dan dimasyrakat. Bentuk yang tepat dari kesalahan penggunaan di sebagai kata depan tersebut adalah di lingkungan, di beberapa, di antaranya, di mana, dan di masyrakat. Kesalahan penulisan ini menunjukkan adanya miskonsepsi yang dialami oleh mahasiswa, yakni kesalahpahaman antara konsep awalan dan kata depan. Awalan merupakn bentuk terikat yang tidak dapat berdiri sendiri, sedangkan kata depan adalah bentuk bebas yang bisa berdiri sendiri.

Selain kesalahan penulisan prefiks $d i$ - dan kata depan $d i$ seperti yang telah dijelaskan di atas, ditemukan pula kesalahan penulisan prefiks $m e N$-. Contoh kesalahan penulisan prefiks meN- antara lain mempengaruhi dan merubah. Bentuk mempengaruhi merupakan bentukan dari $m e N-i+$ pengaruh. Proses tersebut seharusnya menghasilkan bentuk memengaruhi bukan mempengaruhi karena dalam bahasa Indonesia jika meN- bertemu dengan kata dasar yang diawali konsonan $k, t, s$, dan $p$, fonem awal kata dasar tersebut akan luluh kecuali bertemu dengan gugus konsonan atau kluster. Misalnya, meN- + kunci $>$ mengunci sedangkan meN- + kritik > mengktitik. Selanjutnya bentuk merubah merupakan bentukan dari meN- + ubah yang seharusnya menghasilkan bentuk mengubah. Kesalahan ini merupakan kesalahan akibat interferensi dari bahasa Indonesia sendiri, yakni adanya bentuk berubah dan perubahan yang memengaruhi mahasiswa untuk menuliskan merubah bukan mengubah.

Kesalahan juga ditemukan pada penulisan konfiks. Kesalaan penggunaan konfiks ini ditemukan pada konfiks yang disertai oleh dua kata, misalnya menumbuh suburkan dan menyebar luaskan. Penulisan bentuk-bentuk tersebut seharusnya menumbuhsuburkan dan menyebarluaskan. Karena imbuhannya berupa konfiks meN-kan bukan meN- dan kan, kata dasar tumbuh subur dan sebar luas melebur menjadi satu kata. Kesalahan ini masih sering ditemukan untuk penulisan konfiks yang mengimbuhi dua kata seperti contoh tersebut. Mahasiswa masih cenderung menganggap bahwa dua kata tersebut mendapat imbuhan sendiri-sendiri, padahal tidak demikian.

Kedua, kesalahan pada reduplikasi atau pengulangan kata. Bentuk pengulangan kata dalam bahasa Indonesia ada yang merupakan bentuk pengulangan penuh, sebagian, dan berimbuhan. Kesalahan yang ditemukan dalam proses reduplikasi adalah sebelum- 
belumnya. Kata yang diulang sebelum bukan belum. Pengulangan dalam contoh ini adalah pengulangan berimbuhan.

Ketiga, kesalahan ditemukan pada proses komposisi (pemajemukan). Pemajemukan merupakan proses penggabungan dua morfem dasar atau lebih yang mempunyai makna relatif baru (Muslich, 2006: 57). Penggabungan dua morfem atau lebih ini bukanlah menjadikan dua morfem atau lebih tersebut menjadi satu morfem. Morfem-morfem tersebut tetap berdiri sendiri-sendiri namun memiliki kesatuan makna yang tidak dapat dipisahkan. Morfem-morfem yang bergabung dalam proses pemajemukan merupakan morfem bebas yang dapat berdiri sendiri. Berbeda dengan proses afiksasi yang menggabungkan antara morfem terikat dan morfem bebas. Sehingga, dalam proses pemajemukan penulisan morfem-morfemnya tetap diberi spasi. Pada kenyataannya dalam karya tulis mahasiswa IAIN Ponorogo masih ditemukan kesalan penulisan kata majemuk. Contoh kesalahan penulisan kata majemuk seperti orangtua dan bertanggungjawab. Seharusnya kedua kata tersebut berbentuk orang tua dan bertanggung jawab.

Selain kesalahan penulisan kata majemuk, dalam pemajemukan juga ditemuan satu bentuk kesalahan yakni penulisan kata sosial media. Kesalahan ini terjadi akibat pengaruh dari bahasa Inggris terhadap bahasa Indonesia. Dalam bahasa Inggris kata tersebut adalah social media yang jika diterjemahkan ke dalam bahasa Indonesia menjadi media sosial karena pola kedua bahasa tersebut berbeda, namun mahasiswa IAIN Ponorogo masih menerjemahkannya kata per kata. Kasus seperti ini dalam istilah Sosiolinguistik disebut dengan interferensi. Kasus interferensi bahasa Inggris ke dalam bahasa Indonesia sedang marak terjadi di masyarakat Indonesia. Misalnya, Rudi Salon yang seharusnya dalam bahasa Indonesia adalah Salon Rudi. Hal ini terjadi karena pemaknaan kata per kata.

Keempat, ditemukan kesalahan pada bentukan kata yang huruf terakhirnya sama dengan huruf pertama akhirannya. Kesalahan terjadi pada kata yang berakhiran huruf $n$ kemudian mendapat akhiran -nya maka $n$ yang pertama lebur dan kata yang berakhiran huruf $k$ kemudian mendapat akhiran -kan maka konsonan $k$ yang pertama lebur. Contoh untuk kasus ini terdapat pada kata digunakanya dan mempraktekan. Kasus tersebut merupakan kesalahan yang disebabkan oleh pengaruh bahasa lisan. Dalam bahasa lisan pengucapan huruf ganda tidak ditunjukkan dengan jelas, seolah-olah harufnya hanya satu.

Kelima, kesalahan penulisan kata terikat dalam bahasa Indonesia. Kata terikat tidak dapat berdiri sendiri sehingga penulisannya harus dirangkai dan tidak perlu diberi tanda hubung. Contoh bentuk kesalahan ini adalah multi etnis dan non-fisik. Bentuk ini seharusnya adalah multietnis dan nonfisik. Kesalahan ini merupakan akibat dari ketidakpahaman mahasiswa terhadap bentuk terikat. Bentuk terikat yang lebih dari satu suku kata seolah-olah dianggap sebagai satu morfem yang dapat berdiri sendiri. Pada contoh kesalahan penulisan bentuk terikat tersebut juga disebabkan oleh kesalahpahaman mahasiswa terhadap kata non-. Kata ini dianggap bahasa asing sehingga penulisannya menggunakan tanda hubung. Padahal kata non- merupakan kosakata dalam bahasa Indonesia.

\section{Kesalahan Berbahasa Indonesia pada Penggunaan Kata Baku}


Kata baku digunakan dalam komunikasi yang situasinya resmi. Kata baku dapat ditemukan dalam Kamus Besar Bahasa Indonesia (KBBI). Kesalahan penggunaan kata baku dipengaruhi oleh faktor "kebiasaan". Kebiasaan yang dimaksud di sini adalah umumnya kata tersebut digunakan dalam komunikasi. Padahal kata yang umum digunakan tersebut belum tentu sesuai dengan aturan kata bakudalam KBBI.

Beberapa kesalahan kata baku yang ditemukan dalam karya tulis ilmiah mahasiswa PGMI adalah faham, mempraktekan, aktifitas, murit, menggrogot, system, vormal, obyek, subyek, fikir, tekhnologi, dan lain-lain. Berdasarkan KBBI (Badan Bahasa Kemendikbud RI, 2018) kata-kata tersebut seharusnya paham, mempraktikkan, aktivitas, murid, menggerogot, sistem, formal, objek, subjek, pikir, dan teknologi. Kesalahan penggunaan kata baku ini tidak hanya ditemukan pada satu mahasiswa. Jadi kesalahan yang sama dilakukan oleh beberapa orang. Hal ini menunjukkan kurangnya pemanfaatan KBBI oleh mahasiswa dan kebiasaan yang salah dan dianggap benar.

\section{Kesalahan Berbahasa Indonesia pada Tataran Sintaksis (Kalimat Efektif)}

Penggunaan kelimat efektif bertujuan untuk menciptakan kesalingpahaman antara pembicara atau penulis dengan pendengar atau pebaca dalam suatu komunikasi. Kalimat efektif bukanlah kalimat yang harus pendek karena ukuran kefektifan suatu kalimat adalah kesamaan informasi yang disampaikan. Ciri-ciri kalimat yang efektif adalah memenuhi kriteria: kelugasan, ketepatan, kehematan, dan kesejajaran (Sasangka, 2014: 54-55). Akan tetapi, sering ditemukan kasus semakin penjang kalimat yang digunakan pembicara atau penulis untuk menyampaikan gagasannya tingkat pemahaman pendengar atau pembaca pun semakin rendah.

Pertama, kesalahan ditemukan pada ciri kelugasan. Kelugasan dalam kalimat efektif mensyaratkan bahwa informasi yang akan disampaikan dalam kalimat itu ialah yang pokok-pokok saja (yang perlu-perlu atau yang penting-penting saja), tidak boleh berbelitbelit, tetapi disampaikan secara sederhana (Sasangka, 2014: 55). Contoh yang menunjukkan kesalahan ini dituliskan di bawah ini.

Pembangunan karakter bangsa merupakan gagasan besar yang disampaikan para pendiri bangsa karena sebagai bangsa yang terdiri atas berbagai suku bangsa dan nuansa kedaerahan yang kental, bangsa Indonesia memerlukan pandangan yang sama tentang budaya dan karakter bangsa.

Kalimat tersebut merupakan kalimat yang berbelit-belit. Ada dua gagasan pokok dalam kalimat tersebut, sehingga dapat dipecah menjadi dua kalimat. Gagasan tersebut yaitu (1) pembangunan karakter bangsa merupakan gagasan besar yang disampaikan para pendiri bangsa karena bangsa yang terdiri atas berbagai suku bangsa dan nuansa kedaerahan yang kental dan (2) Bangsa Indonesia memerlukan pandangan yang sama tentang budaya dan karakter bangsa. Kedua gagasa tersebut dapat dirangkai agar menjadi gagasan yang padu menggunakan konjungsi antar kalimat oleh karena itu.

Kedua, kesalahan ditemukan pada ciri ketepatan. Ketepatan dalam kalimat efektif mensyaratkan bahwa informasi yang akan disampaikan dalam kalimat itu harus jitu atau kena benar (sesuai dengan sasaran) sehingga dibutuhkan ketelitian (Sasangka, 2014: 58). 
Syarat kalimat efektif harus memenuhi ciri ketepatan adalah dalam kalimat efektif maksud harus tersampaikan dengan jelas tidak boleh terjadi multitafsir atau ketaksaan pada pembaca. Contoh kalimat yang tidak sesuai dengan ciri ketepatan dituliskan di bawah ini.

Suasana lingkungan menjadi hidup dinamis, agamis, harmonis serta menyenangkan hati masyarakat yang tinggal di lingkungan tersebut.

Ketaksaan kalimat terletak pada kata hidup. Hidup dalam kalimat tersebut dijelaskan oleh kata dinamis atau berdiri sendiri. Jika kata hidup dijelaskan oleh kata dinamis, gagasan akan menjadi suasana lingkungan menjadi hidup dinamis, .... (1). Gagasan tersebut tidak logis karena suasana tidak bisa menjadi suatu kehidupan yang dinamis. Berbeda jika diberi tanda koma (,) setelah kata hidup, sehingga gagasan menjadi suasana lingkungan menjadi hidup, dinamis, .... (2). Gagasan ke-2 ini lebih logis karena suasana bisa menjadi hidup.

Ketiga, kesalahan ditemukan pada ciri kejelasan. Kejelasan dalam kalimat efektif mensyaratkan bahwa kalimat itu harus jelas strukturnya dan lengkap unsur-unsurnya (Sasangka, 2014: 64). Kejelasan struktur ini mengacu pada kejelasan subjek (S) dan presdikat $(\mathrm{P})$ dalam sebuah kalimat. Subjek dan predikat merupakan intik dari sebuah kalimat, sehingga keduanya harus jelas keberadaannya. Sumadi juga menyatakan bahwa kalimat yang lengkap adalah kalimat yang memiliki fungsi S dan P (Sumadi, 2009: 165). Hal ini menunjukkan bahwa $\mathrm{S}$ dan $\mathrm{P}$ adalah inti kalimat. Contoh kalimat tidak efektif yang tidak sesuai dengan ciri ini dijelaskan berikut.

Diera globalisasi, dan teknologi semakin canggih banyak para pelajar yang tidak menggunakan bahasanya sendiri bahkan melupakannya.

Kalimat di atas merupakan kalimat yang tidak efektif karena subjeknya tidak jelas. Seolah-olah subjek kalimat tersebut adalah di era globalisasi dan teknologi kemudian predikatnya adalah semakin canggih. Kalimat tersebut menimbulkan kebingungan pemahaman pembaca karena ketidakjelasan subjek dan predikat. Padahal sebenarnya yang menjadi subjek adalah banyak para pelajar. Diera globalisasi, dan teknologi semakin canggih adalah keterangan yang berada di awal kalimat. Namun ada konjungsi yang hilang sehingga menimbulkan masalah dalam kalimat tersebut. Konjungsi tersebut adalah yang. Kalimat tersebut seharusnya adalah Di era globalisasi dan teknologi yang semakin canggih, banyak para pelajar yang tidak menggunakan bahasanya sendiri bahkan melupakannya.

Keempat, kesalahan ditemukan pada ciri kehematan. Kehematan dalam kalimat efektif mensyaratkan bahwa informasi yang akan disampaikan dalam kalimat itu harus cermat, tidak boros, dan perlu kehati-hatian. Untuk itu, perlu dihindari bentuk-bentuk yang bersinonim (Sasangka, 2014: 74). Sinonim sering disebut dengan "persamaan kata". Konsep ini adalah konsep yang kurang tepat. Sinonim bukanlah "persamaan kata" melainkan persamaan "makna". Seperti halnya yang disebutkan oleh Wijana bahwa sinonim adalah persamaan makna. Persamaan makna di dalam sinonim bukanlah persamaan yang sama persis (saling menggantikan, karena ada kata yang bersinonim tapi tidak bisa saling menggantikan. Hal ini menunjukkan bahwa sinonim tidaklah bersifat 
menyeluruh (Wijana, 2010: 54). Kata yang bersinonim seutuhnya maupun tidak seutuhnya dalam sebuah kalimat cukup dituliskan satu kali. Jika dituliskan berkali-kali akan terjadi pengulangan informasi yang sama. Hal ini menyebabkan kalimat menjadi tidak efektif. Data yang menunjukkan ketidakhemaatan kata adalah contohnya: misalnya home schooling pada beberapa keluarga atlet tenis, keahlian musik, kegiatan sosial dan kegiatan keagamaan. Kata contohnya dan misalnya merupakan dua kata yang bersinonim dan kalimat akan efektif kalau tidak mengulang-ulang kata yang bersinonim.

Kelima, kesalahan ditemukan pada ciri kesejajaran. Kesejajaran dalam kalimat efektif mensyaratkan bahwa bentuk dan struktur yang digunakan dalam kalimat efektif harus paralel, sama, atau sederajat (Sasangka, 2014: 76). Contoh kalimat tidak efektif yang menunjukkan ketidaksejajaran ditunjukkan pada kalimat di bawah ini.

Dalam keluarga akan tertanamkan seperti religius, memiliki rasa tanggungjawab, percaya diri, kerja keras, etika sopan santun, jujur, patuh terhadap aturan sosial, disiplin, mandiri, berfikir kritis, logis, kreatif, dan inovatif.

Kalimat di atas menunjukkan ketidaksejaraan pada bagian-bagian yang dirinci, yakni pada bagian memiliki rasa tanggung jawab dan berfikir kritis. Bagian yang lain merupakan kata/frasa adjektiva, sedangkan memiliki rasa tanggung jawab dan berfikir kritis merupakan frasa verba. Kalimat tersebut akan efektif jika frasa verba tersebut diubah menjadi frasa adjektiva. Sehingga bentuk kalimat efektifnya adalah Dalam keluarga akan tertanamkan seperti religius, tanggung jawab, percaya diri, kerja keras, etika sopan santun, jujur, patuh terhadap aturan sosial, disiplin, mandiri, kritis, logis, kreatif, dan inovatif.

\section{E. Masa Depan Bahasa Indonesia yang Terefleksi dalam Karya Tulis Mahasiswa}

Mahasiswa merupakan generasi penerus bangsa yang berpengaruh terhadap perkembangan bahasa negaranya karena dalam dunia pendidikan mereka menerapkan penggunaan bahasa Indonesia. Sikap mahasiswa terhadap bahasanya menjadi penentu masa depan bahasa Indonesia. Sikap bahasa merupakan sikap seseorang terhadap bahasanya. Sifat ini bisa positif atau negatif. Sikap bahasa merupakan salah satu penyebab terjadinya kesalahan berbahasa (Ihemere dalam Marnita AS, 2011: 148). Jadi, sikap pengguna bahasa Indonesia, khususnya mahasiswa, dapat berpengaruh terhadap masa depan bahasa Indonesia, yaitu tetap kokoh atau akan tergeser.

Berdasarkan hasil analisis kesalahan berbahasa yang ditemukan pada bagian sebelumnya dapat direfleksikan masa depan bahasa Indonesia di kalangan mahasiswa. Beberapa kasus kesalahan adalah kesalahan-kesalahan kecil yang seharusnya tidak terjadi. Misalnya setelah tanda baca titik atau koma seharusnya diberi spasi, tapi kesalahan ini masih banyak dilakukan oleh mahasiswa. Ada pula kasus ketidakkonsistenan mahasiswa dalam menggunakan kata majemuk, yakni kata orang tua, ditinggalkan, di padu, dan jaman. Bentuk tersebut adalah bentuk-bentuk yang tidak baku. Namun, dalam satu karya tulis, mahasiswa kadang menggunakan kata-kata tersebut dalam bentuk yang baku. Hal ini menunjukkan bahwa sebenarnya mahasiswa tahu kaidah 
yang benar tetapi mereka tidak peduli akan hal tersebut dan menuliskan semau mereka. Kemungkinan kedua mereka memang tidak memahami penulisan kata majemuk. Kondisi seperti ini menunjukkan sikap negatif mahasiswa terhadap bahasa Indonesia dan hal ini akan mengancam tatanan bahasa Indonesia yang baku. Sehingga pada akhirnya tatanan bahsa Indonesia baku lambat laun akan menghilang.

\section{SIMPULAN}

Dalam analisis data ditemukan kesalahan berbahasa pada krya tulis mahasiswa. Bentuk kesalahan tersebut meliputi kesalahan ejaan, morfologi, kata baku, dan kalimat efektif. Bentuk kesalahan ejaan meliputi kesalahan penggunaan tanda koma (,), tanda baca ganda, huruf kapital, huruf miring, tanda titik koma (;), dan tanda hubung (-). Bentuk kesalahan morfologi meliputi kesalaan afiksasi, reduplikasi, dan komposisi. Bentuk kesalahan kata baku meliputi kesalahan penulisan yang kata yang tidak sesuai dengan bentuk baku di KBBI. Bentuk kesalahan kalimat efektif merupakan kesalahan pada kalimat yang tidak lugas, ambigu, tidak jelas, berbelit-belit, dan tidak sejajar.

Sikap bahasa yang ditunjukkan oleh mahasiswa ini merupakan sikap bahasa yang negatif. Sebagian kasus menunjukkan bahwa sebenarnya mahasiswa mengetahui kesalahannya tapi enggan atau tidak peduli dengan hal yang sepele. Jika dibiarkan terus menerus maka bahasa Indonesia yang baku lambat laun akan memudar digantikan dengan bahasa Indonesia yang tanpa aturan.

\section{DAFTAR RUJUKAN}

Marnita AS., R. (2011) "Pergeseran Bahasa dan Identitas Sosial dalam Masyarakat Minangkabau Kota: Studi Kasus di Kota Padang”. Jurnal Masyarakat Indonesia, Edisi XXXVII No. 1 Tahun 2011, hlm. 139-163.

Ayudia, Edi S., \& Budhi W. (April, 2016). “Analisis Kesalahan Penggunaan Bahasa Indonesia dalam Laporan Hasil Observasi pada Siswa SMP”. Jurnal BASASTRA. Vol. 4, No. 1, hlm. 34-49.

Badan Bahasa Kemendikbud RI. (2018). KBBI Daring Versi V. Dipetik Juni 11, 2018, dari https://kbbi.kemdikbud.go.id/

Endarmoko, E. ( 2017). Remah-Remah Bahasa: Perbincangan dari Luar Pagar. Yogyakarta: Bentang.

Johan, G. M. \& Yusrawati JR. S. (Desember, 2017) “Analisis Kesalahan Berbahasa Indonesia secara Sintaksis dalam Proses Diskusi Siswa Kelas IV SDN Miri," Jurnal Visipena, Vol. 8, No. 2, hlm. 241-253.

Katamba, F.. (1993). Morphology. London: Macmillan Press Ltd.

Muslich, M. (2009). Tatabentuk Bahasa Indonesia: Kajian ke Arah Tatabahasa Deskriptif. Jakarta: Bumi Aksa. 
Pusat Bahasa Departemen Pendidikan Nasional. (2001). Bahan Penyuluhan Bahasa Indonesia: Ejaan. Jakarta: Departemen Pendidikan Nasional.

Santoso. (2017). "Penanaman Nilai-Nilai Karakter pada Siswa SD pada Era Globalisasi." Dalam Prosiding Seminar Nasional Aktualisasi Kurikulum 2013 di Sekolah Dasar melalui Gerakan Literasi Sekolah untuk Menyiapkan Generasi Unggul dan Berbudi Pekerti, 164-170. Kudus: Badan Penerbit Universitas Muria Kudus.

Sasangka, S. S. (2014). Kalimat (Seri Penyuluhan Bahasa Indonesia). Jakarta: Badan Pengembang dan Pembinaan Bahasa Kemendikbud RI.

Sudaryanto. (1992). Metode Linguistik: Ke Arah Memahami Metode Linguistik. Yogyakarta: Universitas gadjah Mada Press.

Sumadi. (2009). Sintaksis Bahasa Indonesia. Malang: A3 (Asih Asah Asuh).

Supriani, R. \& Ida R. S. (2016). "Penelitian Analisis Kesalahan Berbahasa”. Jurnal Edukasi Kultura. Vol. 1 No.2, hlm. 67-76.

Tim Pengembang Pedoman Bahasa Indonesia. 2016. Pedoman Umum Ejaan Bahasa Indonesia. Jakarta: Badan Pengembang dan Pembinaan Bahasa Kemendikbud RI.

Wijana, I. D. P. (2010). Pengantar Semantik Bahasa Indonesia. Yogyakarta: Pustaka Pelajar. 
